\title{
Marketing of agroforestry products in Bangladesh: A value chain analysis
}

\author{
Kazi Kamrul Islam ${ }^{1,2}$, Takahiro Fujiwara ${ }^{2}$, Masakazu Tani ${ }^{3}$, Noriko Sato ${ }^{2}$ \\ ${ }^{1}$ Department of agroforestry, Bangladesh Agricultural University, Mymensingh-2202, Bangladesh \\ ${ }^{2}$ Forest Policy Laboratory, Faculty of Agriculture, Kyushu University, Fukuoka, Japan \\ ${ }^{3}$ Faculty of Design, Kyushu University, Fukuoka, Japan
}

\section{Email address:}

kamrulbau@yahoo.com (K. K. Islam), takaf217@gmail.com (T. Fujiwara), mt18916@gmail.com (M. Tani), sato.noriko.842@m.kyushu-u.ac.jp (N. Sato)

\section{To cite this article:}

Kazi Kamrul Islam, Takahiro Fujiwara, Masakazu Tani, Noriko Sato. Marketing of Agroforestry Products in Bangladesh: A Value Chain Analysis. American Journal of Agriculture and Forestry. Vol. 2, No. 4, 2014, pp. 135-145. doi: 10.11648/j.ajaf.20140204.16

\begin{abstract}
Bangladesh agriculture, including agroforestry, is dominated by small-scale subsistence farming; however, farmers do not get proper prices for their products due to the involvement of many intermediaries in its value chain. Therefore, the objectives of this study are to analyze the value chain of main agroforestry products and the position of the various intermediaries within it, and to determine the extent of value addition in terms of costs in successive stages of products movements. The study was conducted in Madhupur Sal forests area of Bangladesh and data were collected through questionnaire interviews, focus group discussion, observation and literature review. In analyzing network structures of value chain, the study found that both agroforestry crops and timber marketing have regulated a number of intermediaries which enhanced value addition and created high marketing margins of products. Moreover, farmers had possessed strong negative relationship with intermediaries and that the lack of a farmer organization severely affected farmers' free and fair access to local markets to sell their products. So, there is an immediate need to establish farmers' cooperatives in order to reduce unexpected intermediaries from value chain to get fair prices of their products, and to harmonize and execute marketing legislations.
\end{abstract}

Keywords: Agroforestry, Value Chain, Intermediaries, Marketing Margin, Sal Forests, Bangladesh

\section{Introduction}

Marketing systems plays a significant role in enhancing production and consumption, and in accelerating the pace of economic development $[1,2]$. At the same time, the marketing of agriculture and small scale forestry products plays a major role in smallholders' economy which are both produced and consumed locally. These products are contributing to a significant role in developing countries because these products make a major contribution to the GDP, and their consumption represents an important part of rural people's expenditure $[3,4]$.

The analysis of marketing systems, particularly value chain analysis provides the full range of activities which are required to bring a product from conception, through the primary phases of production and delivery to final consumers $[5,6]$. As a product goes from the producer to the consumer, a number of transformations and transactions take place along a chain of interconnected activities, and value is added continuously at each level of the chain [7]. Production, standardization, pricing and distribution .of agricultural and small scale forestry products are progressively being organized into value chains, where the movements of products have effected farmers, wholesalers, retailers and other intermediaries. Value chain analysis analyze the organization and behavior of all the actors in the value chain, and also delivers the distribution of value added over various actors. It also express the achievements of all intermediaries/actors in participating the chain [8].

In developing countries including Bangladesh, local product-based marketing channels are characterized by high instability and complexity. Literature also revealed that the structure of value chain has included a number of intermediaries who are playing dominant roles in making the agriculture market unstable and risky by grabbing major portions of the benefit from the farmer and by gaining high 
profits from the consumer by fixing the high prices of products $(9,10,11,12,13,14,15)$. In developing countries, it is nearly impossible to imagine a market without middlemen $[2,4,16]$. On the contrary, there are many reasons for involving intermediaries in the value chain. Their important functions includes they are specializing at transportation, selling and even processing functions of marketing, the average costs of performing the marketing functions falls as the volume of products handled rises, intermediaries can take the risks, and handling large volume of products and can reduce market search and transactions costs [4]. This does not means that all intermediaries are efficient and necessary, nor that farmers should never implement their own marketing functions. Recent literatures also found that creating farmer cooperatives or institutions would forfeit these economic gains from specialization and scale economies $[4,17,18$, 19, 20].

Bangladesh agriculture is dominated by small scale farming; more than $80 \%$ of Bangladeshi people are directly or indirectly involved in agriculture [21, 22]. The agriculture sector contributes $21.11 \%$ of the total GDP share, and the non-farm sector, which is also driven primarily by agriculture, has contributed another $33 \%$ in Bangladesh [22, 23]. Nowadays, smallholders are more interested in practicing agroforestry (combining agriculture and forestry) in order to produce more integrated, diverse and profitable products. Due to a huge demand of firewood in local markets, agroforestry practices are gaining more preference in Bangladesh $(14,24)$. Agroforestry programs in Madhupur Sal forest area have been contributing to a substantial economic output to the Bangladesh Forest Department (FD) and local people since 1989 [25, 26, 27] because these programs are considered to be of more environmental and economic importance [14, 25, 28]. Since agroforestry production in Bangladesh is increasing over the recent years, its value chain analysis is very important for farmers, intermediaries and consumers because all are affected due to value addition in marketing systems. There were very few empirical study on value chain analysis of agroforestry products in Bangladesh, so, this study takes the leading steps to analyze value chain of agroforestry products. Therefore, the objectives of this study is to identify different value chains of agroforestry products and the position of the various intermediaries within it, and also to determine the extent of value addition in terms of costs in successive stages of agroforestry products movements.

\subsection{Theoretical Frameworks}

In the recent decades, there were many extensive theories introducing in the area of value chains, reflected in various concepts and approaches [29, 30]. These approaches vary mainly in their objectives, in the activity that is underlined, and in the pathway in which they have been applied [31]. Value chain analysis in developing countries are characterized by its network structure, its governance form and the way value is added [29, 30, 32]
These approaches emphasized value chains as production networks in which actors exploit competitive resources and function within an organized environment. Therefore, the developing countries value chain approaches have three main components: network structure, value added and governance structure.

The structure of value chain network has vertical and horizontal dimensions. The vertical dimension of value chain refers the flow of products from an initial producer up to the last consumer and the horizontal dimension reflects the relationship between stakeholders in the same chain link (e.g. farmer to farmer). Lazzarini et al (2001) developed the concept of netchain (Figure 1) which shows vertical relationships between the several value chain links and horizontal relationships between stakeholders' in the same link. Figure 1 explains that vertical relationship may follow all stages in the value chain or may not, and horizontal relationships between stakeholders have various shapes [29, 30, 33], such as farmer cooperatives or price agreements between wholesalers. Market channels have vertically structured the value chain network and horizontal dimension is shaped by purchase, production and delivery dependencies between stakeholders that are situated in the same value chain $[4,30]$. So, the structure of a value chain network is the principle dynamics of all sectors of the economy [30, 34].

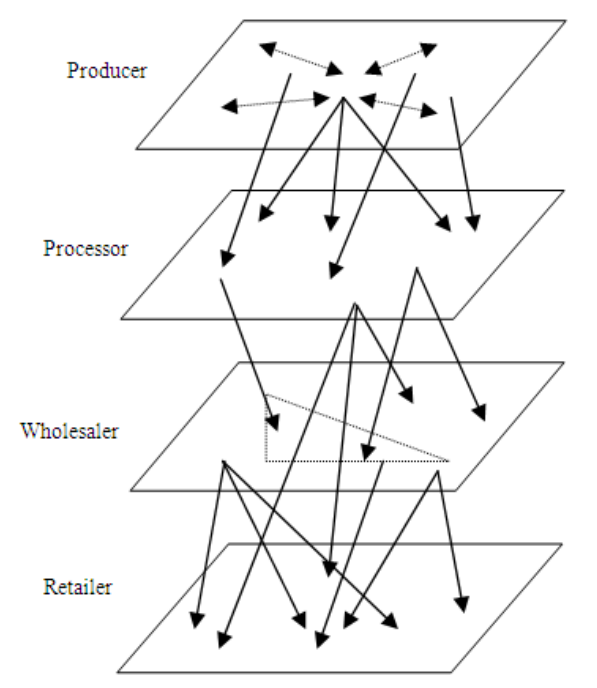

Figure 1. Netchain (adopted from Lazzarini et al. 2007)

Value added is the amount by which the value of a product is increased in each stage of its distribution channel, exclusive of initial costs; and is created by different stakeholders throughout the value chain. Value added may relates to quality, costs, delivery frequencies and flexibility, etc. [30]. The amount of value added is decided by the last level consumer's willingness to pay. The value addition in food production mainly depends on the safety and quality of the products, and the quality can be divided in two intrinsic (e.g. color, size, taste. etc.) and extrinsic (organic or inorganic production) characteristics of the product [30]. So, value added is generated in value chains aiming at particular 
markets and composing a number of stakeholders. Regarding to governance, stakeholders in value chains are linked in a variety of sourcing and contracting relationships, which means the forms of governance [30, 35, 36]. Governance refers as "authority and power relationships that determine how financial, material and human resources are allocated and flow within a chain" [34]. There are many dimensions in explaining the governance $[37,38,39]$ and a major segment of governance depends on global value chain perspectives which is quite hard to relate within a local value chain analysis. Therefore, the present study mainly focuses on network structure and value addition aspects of agroforestry products value chain analysis.

\section{Methodology}

\subsection{Study Area}

Sal forests of Bangladesh cover an area of 0.12 million ha [40] and Madhupur Sal forests are situated in Tangail and Mymensingh Districts possess the majority of the Bangladesh Sal forests [24, 27, 28]. The study was conducted in Madhupur Sal forests (Figure 2) area of Bangladesh where the agroforestry systems were very famous and well established.

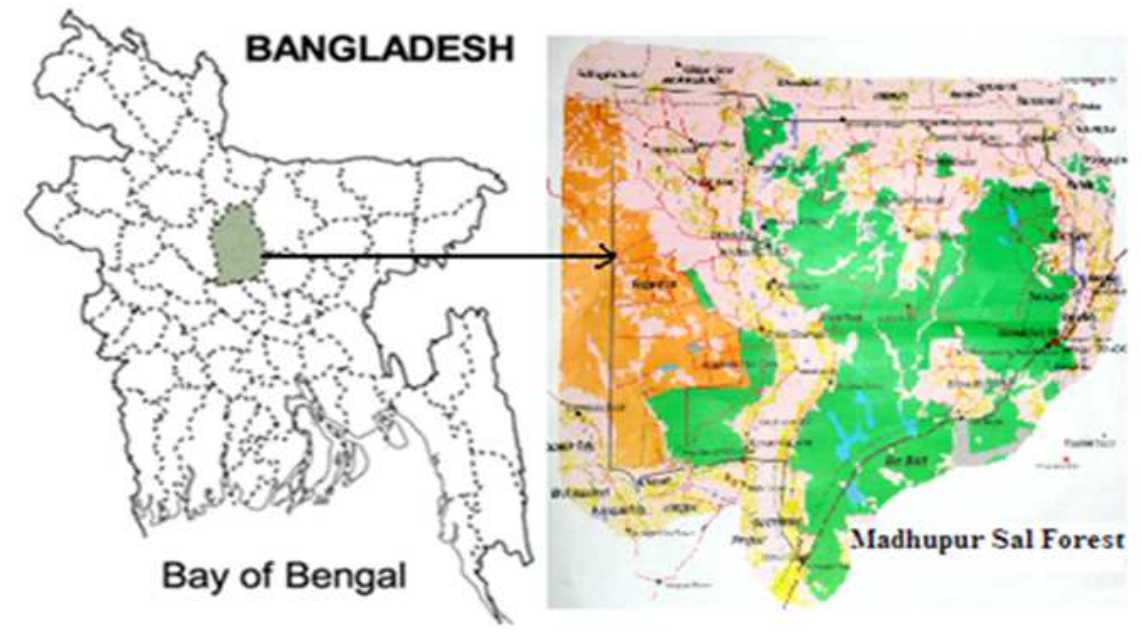

Figure 2. Study area (Madhupur Sal forests)

\subsection{Description of Agroforestry Programs}

Agroforestry programs were very popular and well accepted mainly at the degraded area of Madhupur Sal forests, which were initiated by the Asian Development Bank (ADB) funded project in 1989 [27, 40, 41]. In this program, each participants was allocated 1ha of degraded Sal forest land where they utilized a prescheduled agroforestry model for a 10-year cycle. Each participant can continue up to 3 cycles if they maintain FD prescribed criteria properly. This model provided alternating space for trees and agriculture crops. Approximately 750 trees per ha ${ }^{-1}$ were planted in this process, and a $50 \%$ thinning operation was implemented in

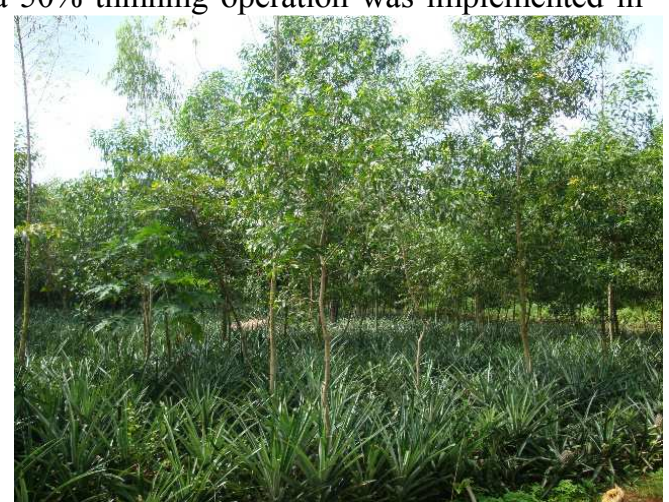

a. Common Agroforestry practice the $7^{\text {th }}$ year of the cycle (Figure $3 \mathrm{~b}$ ). The remaining 375 trees were finally harvested at the end of the 10-year cycle, and the benefits were equally shared with FD [24]. Mainly farmers (more than $80 \%$ ) are plating Acacia auriculiformis as fast growing fuelwood tree species and pineapple as shade loving crops in tree-crop based agroforestry systems at Madhupur Sal forests area [24, 25]. The most significant aspect of this model was the whole crop benefits belonged to the participants (Figure 3). Agroforestry programs practiced in degraded Sal forests land were mainly controlled by the FD, and the local people were the participants who enjoyed a certain amount of user rights.

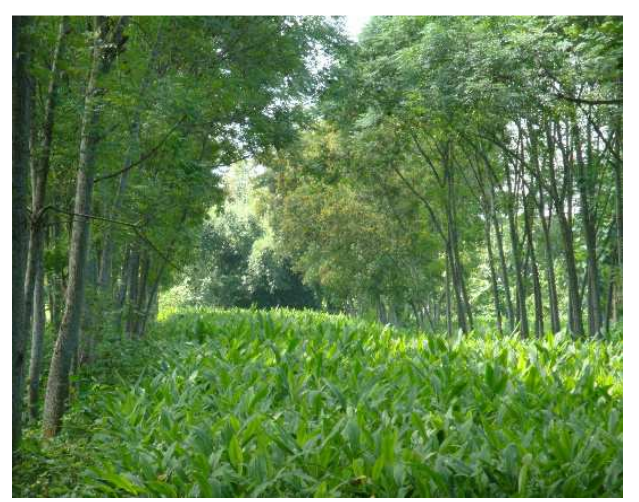

b. FD run Agroforestry model

Figure 3. Agroforestry practices practiced at Madhupur Sal forests area 
Besides FD programs, farmers can practice different tree-crop based agroforestry practices in their homestead, fallow land, cropland, road side and other areas (Figure 3). Other than Acacia spp. farmers planted fast growing firewood species such as Bokain (Melia azedarach) and Gamar (Gmelina arboria) and shade loving crops, Ginger and Turmeric in the study area.

\subsection{Sampling and Data Collection}

About 3,327 participants were involved in FD run Agroforestry programs in Madhupur Sal forests, and a majority of the participants were poor (Islam and Sato 2012a). So, this study included all types of agroforestry production systems in Madhupur Sal forests area, and in total 110 respondents were randomly selected for interviews. Of them, 80 respondents were from FD run programs, and 30 from other agroforestry programs. The participants were living in and around the Sal forests. Though the participants were already certified as poor by FD [28] but for the purposes of this study, only the small scale farmers having less than two hectare farmland were selected for interviews.

This study covered a local market (Jalsatropur) and another two important urban markets in Mymensingh and Dhaka city, for selecting intermediaries of phoria, bepary, paiker/arathdar, and retailer (see description in Results section). In agroforestry firewood marketing includes some other intermediaries, such as auctioneers, local traders, local saw-mills, brickfields and wholesalers. This study also conducted two focus group discussions (10 farmer in each discussion) and asked farmer to identify 5 intermediaries (next to the farmer link in the value chain). Another 5 intermediaries were sampled randomly in the markets area and along the side of the road where they were buying and selling agroforestry products. This process of sampling was continuing up to the last level of intermediaries. Finally, the study selected 10 intermediaries for each category and 20 consumers for data collection. Data were collected in different months of 2009 to 2014 through practical observations, questionnaire interviews, focus group discussion, FD staff interview and literature review.

\section{Results}

\subsection{Descriptions of the Farmer and Intermediaries}

\subsubsection{Farmer}

The average family size of the farmer was 5.62, which was larger than the national average family size of 4.8 (Table 1) [42]. The literacy rate of the farmers indicated that the majority of the farmers were not literate enough to communicate or get marketing information (Table 1). In the case of farmer ethnicity, the majority of them were nonethnic (Bengali people) $(80.3 \%)$ and the remaining were ethnic (29.7\%) (Table 1). Historically ethnic people (mainly
Garo and a few Koch people) have been living all over the Madhupur Sal forests for many decades [43] were also practiced agroforestry programs. Regarding to farmer household origin; about $96 \%$ of the ethnic farmers originated from the same area whereas the majority of nonethnic farmers (94\%) migrated from other areas. (Table 1).

Table 1. General description of farmer

\begin{tabular}{|c|c|c|c|}
\hline Characteristics & Mean, $\mathbf{N}$ & Percentage & $\pm \mathbf{S D}$ \\
\hline Age & 42.35 & - & 9.24 \\
\hline Household size & 5.62 & - & 1.29 \\
\hline Sex of farmer & & & - \\
\hline Male & 97 & 88 & \\
\hline Female & 13 & 12 & \\
\hline \multicolumn{4}{|c|}{ Ethnicity of farmer } \\
\hline Ethnic & 73 & 80.3 & - \\
\hline Non-ethnic & 27 & 29.7 & \\
\hline \multicolumn{4}{|c|}{ Non-ethnic farmer religion } \\
\hline Muslim & 69 & 94.5 & \\
\hline ...Hindu & 3 & 4.1 & \\
\hline Christian & 1 & 1.4 & - \\
\hline \multicolumn{4}{|c|}{ Ethnic farmer religion } \\
\hline Christian & 21 & 77.8 & - \\
\hline Shangsarek & 4 & 14.8 & \\
\hline Others & 2 & 7.4 & \\
\hline Literacy rate & - & 26.36 & - \\
\hline \multicolumn{4}{|c|}{ Ethnic household origin } \\
\hline Migrate & 1 & 3.7 & - \\
\hline From same area & 26 & 96.3 & \\
\hline \multicolumn{4}{|c|}{ Non-ethnic household origin } \\
\hline Migrate & 69 & 94.5 & \\
\hline From same area & 4 & 5.5 & - \\
\hline
\end{tabular}

\subsubsection{Intermediaries}

Phoria: a phoria purchases products from farmers and deals with small volume of products. They sell products in village markets and sell their whole products to the Bepari (Figure 4). Usually they are small landless farmers/laborers and not involved in full time farming [44]. They possess a small amount of capital, and, in some cases, they will pay farmers after selling products to the Beparies.

Beparies: beparies are professional businessmen who purchase products from the farmers and Phoria. They deal with large amounts of products and often pay phoria for advanced purchasing of local products. Mainly beparies sell their products to paiker/arathdar (Figure 4).

Paiker/Arathdar: a paiker acts as a commission agent between beparies and retailers (Figure 4). They are also called wholesalers in some areas. They have the facilities to store the products and always do tricky business on additional value added to the products. That means, in some cases, they have created an artificial product crisis in the 
market and increase the products price which was also claimed by every farmer.

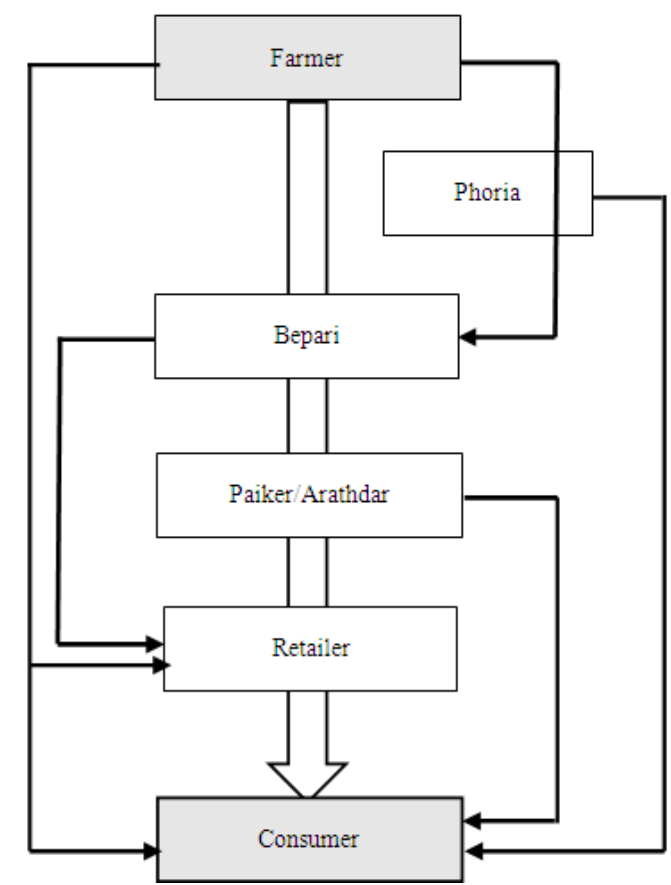

Figure 4. Agroforestry crops distribution channel in Bangladesh

Retailer: retailers are the last level intermediaries in the marketing channel of Bangladesh and other developing countries. They usually handle the consumer and buy products from Paiker and Bepary (Figure 4). They have some additional input costs of renting/buying shops and appointing sells-staff and also have the risk of damaged/rotten products.

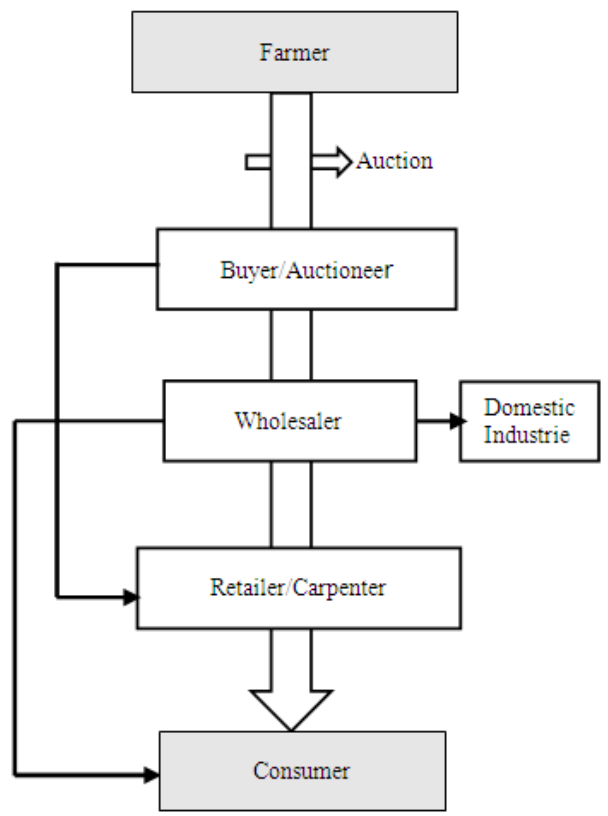

Figure 5. FD controlled agroforestry timber distribution channel in Bangladesh

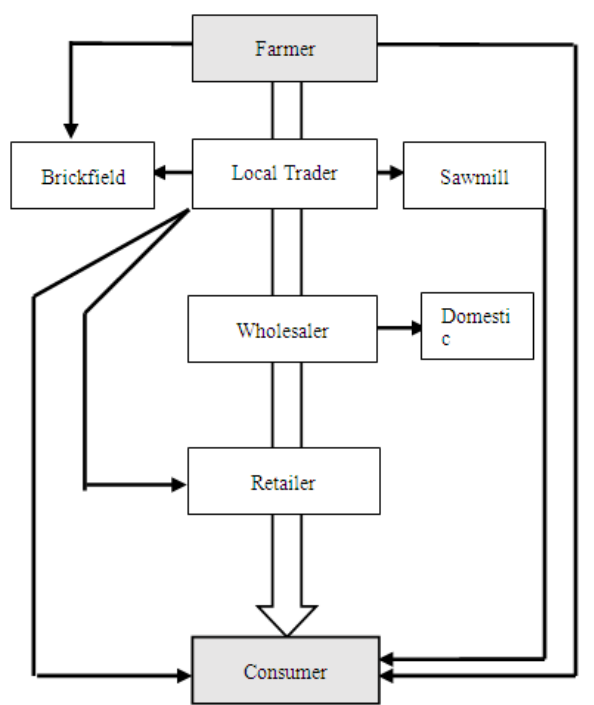

Figure 6. General agroforestry timber distribution channel in Bangladesh

Buyer/Auctioneer: These intermediaries only arise in the FD controlled agroforestry timber/firewood marketing channel. Buyers mainly take part in the open timber auction process. Buyers have to register officially through the FD systems and maintain some criteria imposed by FD. Some buyers have storage facilities and can sell timber to the wholesaler or some time to the retailer (Figure 5). They also maintain a good relationship with FD, local political leaders and the elite in order to buy the products from open auction markets.

Local Timber Trader: This is a very small group of traders and found in timber marketing channel who deals with a small volume of firewood/timber only. Often they collect firewood from farmer's home and sell it to the wholesaler (Figure 6). They also supply firewood to the local saw-mills and brickfields. Usually they have very temporary and small storage facilities.

\subsection{Value Chain Analysis}

\subsubsection{Network Structure}

Network structure of value chain analysis are the possible routes of products flow from farmer to consumers. Vertical structure of value chain may be short or long for a particular products and it depends on product quality, size and the nature of consumers and farmers and the surrounding social and physical environment. Six vertical network structures were identified for agroforestry crops and the main and the most common network structure consists of farmer, phoria, bepary, arathadar, retailer and consumer. Other network structures were: farmer to bepary to arathdar to retailer to consumer; farmer to bepary to retailer to consumer; farmer to bepary to consumer; farmer to retailer to consumer; and farmer to phoria to consumer respectfully. Network structures of agroforestry crops and their mode of action are illustrated in Figure 4. Arrows in Figure 4 show the pathway of agroforestry crop distribution channels and the position of each intermediary in the value chain. In these network structures, the most dominant 
intermediary was bepary followed by paiker/arathdar; and according to the field data bepary handle the major amount of crop products to regulate marketing functions. For example, pineapple farmers sold $80 \%$ of their products to the bepary, $6 \%$ to the phoria, $6 \%$ to the retailer and $8 \%$ to the consumer directly. However, those consumers were situated in local or village areas (Table 2). On the contrary, beparies bought $55 \%$ of pineapple from farmers and $15 \%$ through phorias; while paikers bought $60 \%$ of pineapples from beparies directly. Consumers bought their major percentage of pineapples from retailers $(85 \%)$ and minor percentages from phorias or directly from farmers (Table 2).

Table 2. Buying and selling percentage of pineapple transacted by different intermediaries

\begin{tabular}{|c|c|c|c|c|c|c|c|c|c|c|c|c|}
\hline \multirow{2}{*}{ Intermediaries } & \multicolumn{6}{|c|}{ Buying from (\%) } & \multicolumn{6}{|c|}{ Sold to (\%) } \\
\hline & $\mathbf{A}$ & B & $\mathrm{C}$ & D & $\mathbf{E}$ & $\mathbf{F}$ & $\mathbf{A}$ & B & $\mathrm{C}$ & D & $\mathbf{E}$ & $\mathbf{F}$ \\
\hline Farmer(A) & & & & & & & & 6 & 80 & - & 6 & 8 \\
\hline Phoria(B) & 25 & & & & & & & & 5 & - & - & 1 \\
\hline Bepari(C) & 55 & 15 & & & & & & & & 75 & 10 & - \\
\hline Paiker(D) & - & - & 60 & & & & & & & & 70 & 5 \\
\hline Retailer(E) & 15 & 2 & 10 & 58 & & & & & & & & 86 \\
\hline Consumer(F) & 5 & 8 & - & 2 & 85 & & & & & & & \\
\hline
\end{tabular}

Here $n=10$

Table 3. Buying and selling percentage of agroforestry (FD run) firewood products

\begin{tabular}{|c|c|c|c|c|c|c|c|c|c|c|c|c|}
\hline \multirow{2}{*}{ Intermediaries } & \multicolumn{6}{|c|}{ Buying from $(\%)$} & \multicolumn{6}{|c|}{ Sold to (\%) } \\
\hline & $\mathbf{A}$ & $\mathbf{Y}$ & $\mathbf{W}$ & D & $\mathbf{E}$ & $\mathbf{H}$ & $\mathbf{A}$ & $\mathbf{Y}$ & $\mathbf{W}$ & D & $\mathbf{E}$ & $\mathbf{H}$ \\
\hline Farmer(A) & & & & & & & & 100 & - & - & - & - \\
\hline Buyer(Y) & 100 & & & & & & & & 90 & - & 10 & - \\
\hline Wholesaler(W) & - & 80 & & & & & & & & 5 & 75 & 10 \\
\hline D. Industries(I) & - & - & 5 & & & & & & & & - & - \\
\hline Retailer(E) & - & 20 & 75 & - & & & & & & & & 85 \\
\hline Consumer(H) & - & - & - & - & 95 & & & & & & & \\
\hline
\end{tabular}

Here $n=10$

Table 4. Buying and selling percentage of general agroforestry firewood products

\begin{tabular}{|c|c|c|c|c|c|c|c|c|c|c|c|c|c|c|c|c|}
\hline \multirow{2}{*}{ Intermediaries } & \multicolumn{8}{|c|}{ Buying from (\%) } & \multicolumn{8}{|c|}{ Sold to $(\%)$} \\
\hline & $\mathbf{A}$ & $\mathbf{L}$ & $\mathbf{K}$ & $\mathbf{S}$ & $\mathbf{W}$ & $\mathbf{I}$ & $\mathbf{E}$ & $\mathbf{F}$ & $\mathbf{A}$ & $\mathbf{L}$ & $\mathbf{K}$ & $\mathbf{S}$ & W & $\mathbf{I}$ & $\mathbf{E}$ & $\mathbf{F}$ \\
\hline Farmer(A) & & & & & & & & & & 75 & 5 & 15 & - & - & - & 5 \\
\hline L.Trader(L) & 70 & & & & & & & & & & 5 & 8 & 40 & - & 5 & 17 \\
\hline Brickfield(K) & 5 & 5 & & & & & & & & & & - & - & - & - & - \\
\hline Sawmill(S) & 15 & 8 & - & & & & & & & & & & - & - & - & 23 \\
\hline Wholesaler(W) & - & 35 & - & - & & & & & & & & & & 5 & 35 & - \\
\hline D. Industry(I) & - & - & - & - & 5 & & & & & & & & & & - & - \\
\hline Retailer(E) & 2 & 12 & & - & 30 & & & & & & & & & & & 40 \\
\hline Consumer(H) & 8 & 10 & 0 & 5 & - & - & 44 & & & & & & & & & \\
\hline
\end{tabular}

Here $n=10$

Regarding to agroforestry (FD run) timber vertical network structures analysis, only three different channels were identified and the main network structure comprises of farmer, buyer, wholesaler, retailer and consumer. While other network structures were: farmer to buyer to retailer to consumer; and farmer to buyer to wholesaler to consumer. Figure 5 also shows the position of the intermediaries in the network structure and their mode of actions for agroforestry timber marketing. The results revealed that timber buying rights have solely controlled by the buyer or auctioneer in FD run agroforestry programs. They were the dominant intermediaries in this network and Table 3 clearly shows the amount of timber selling and buying percentages of each intermediaries in this network structures. All most every $(99 \%)$ farmer claimed that buyers had negotiated prior to buy the timber in FD run program.

On the contrary, agroforestry (general) timber products vertical network structure has four different channels and the most common one was farmer to local trader to wholesaler to retailer to consumer. However, other network structures were: farmer to local trader to retailer to consumer; farmer to local trader to consumer; and farmer to local trader to sawmill to consumer. In general agroforestry programs, farmers can directly sold their products to the intermediaries; the position of each intermediary and timer distribution channel are presented in Figure 6. The results also showed that farmers sold their major amount of firewood to the local traders $(75 \%)$, saw-mills $(15 \%)$, brickfields (5\%) and 5\% to the consumers directly (Table 4). However, wholesalers sold $35 \%$ of their products to retailers and some minor percentages to domestic industries (e.g. furniture industries, cottage industries) (Table 4).

The study also identify the horizontal network structures of the stakeholders' in agroforestry products value chain analysis in terms of relationship. In a measurement scale of $+2,+1,0,-1,-2(+2=$ strongly positive relationship, $0=$ no 
relationship or don't know and $-2=$ strongly negative relationship), the results found that farmers did not possess a strong relationship among farmers while farmers had a strong negative relationship with the beparies and other intermediaries (Figure 7). The study also asked for farmer cooperatives or institutions, and the results found that farmer did not have any types of cooperatives among themselves. However, the dominate intermediaries (Bepary) possessed a strong positive relationship among them. Thus, they can easily negotiated among them to fix crop buying prices. Even the other intermediaries (both in crop and timber) had possessed strong positive relationship among themselves (Figure 7). The strong positive relationship among the intermediaries provided a favorable atmosphere towards value addition and fixing price of products in marketing systems. On the contrary, the antagonistic relationship that the farmer had with their next level intermediaries and other intermediaries had a severe impact on free and fair access to sell their products in markets.

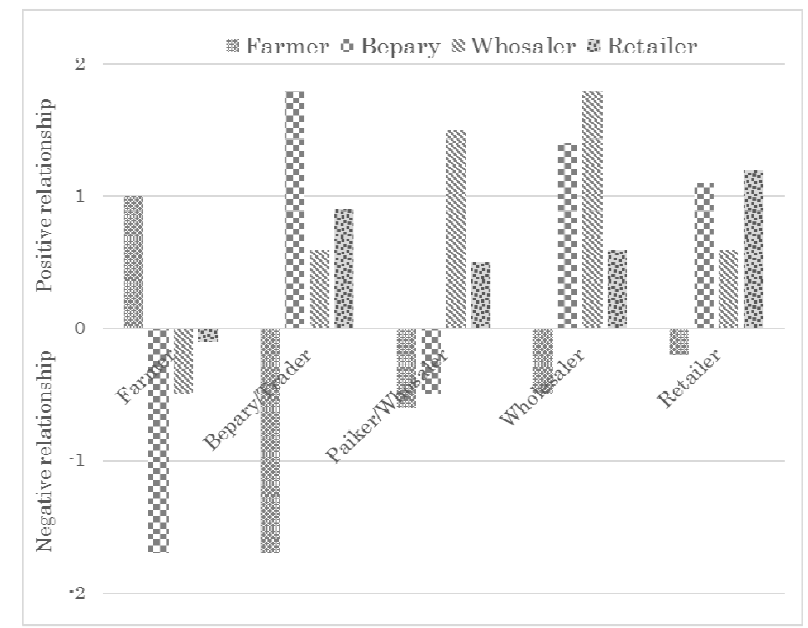

Figure 7. Overall social relationship of the stakeholders

\subsubsection{Value Added}

In value chain analysis, value added is created at different levels with the intervention of different intermediaries throughout the whole products distribution channel. To understand the value addition the study first identified the intermediary-wise and total marketing costs of agroforestry products. Marketing costs are incurred when products are dispatched from the farmer to the consumer. Intermediary-wise costs of main agroforestry crop (Pineapple) and timber (Acacia) are presented in Table 5 and Table 6 respectively. Table 5 showed marketing costs of pineapple includes all costs incurred by different intermediaries such as phoria, bepary, paiker, retailer and farmer. Pineapples got added value during their distribution across the value chain network. Results revealed that the share of transportation cost was the highest $(50.86 \%)$ followed by damaged (15.48\%) and labor wages $(5.53 \%)$ (Table 5). The total value added cost per 100 pineapples was Taka 1815.8 from production to consumption. Among the intermediaries, the retailer total cost was the highest followed by the paiker (Table 5).

Similarly, Table 6 observed that the total cost of 1 mon (40kg) acacia timer was Taka 81.5. Like pineapples, the acacia timber transportation costs $(40.49 \%)$ ranked the top followed by labor wages $(14.72 \%)$. Regarding the intermediaries, wholesaler's value added costs was the highest followed by Retailer's (Table 6). Furthermore, the value addition scenario of a pineapple is clearly presenting in Figure 8. Famer price of a pineapple was only Taka 10 and when it run through the different marketing channels the total value addition cost was Taka 25; that means the consumer bought the pineapple at Taka 35 (Table 7).

The results showed the marketing margin for pineapple was $71.43 \%$, ginger $44 \%$ and Acacia timber $36.84 \%$ (Table 7). That means an average pineapple marketer earns a market margin (farmer to retail price spread) of 0.71 Taka for every 1 Taka retail price paid by the ultimate consumer in the marketing channel in Bangladesh. This represents payments for all marketing chargers including intermediaries' commission added to farmer products.

Table 5. Total marketing costs of different intermediaries involved in Pineapple marketing

\begin{tabular}{|c|c|c|c|c|c|c|c|}
\hline \multirow{2}{*}{$\begin{array}{c}\text { Cost Items } \\
\text { (per } 100 \text { pineapple) }\end{array}$} & \multicolumn{5}{|c|}{ Intermediaries } & \multirow{2}{*}{ Total } & \multirow{2}{*}{$\%$ of total costs } \\
\hline & Farmer & Phoria & Bepary & Paiker & Retailer & & \\
\hline Transportation & 111.5 & - & 219 & 321 & 272 & 923.5 & 50.86 \\
\hline Fruit mulching & - & 37 & 60 & - & - & 97 & 5.34 \\
\hline Labor wages & 10 & 15 & 25.5 & 20 & 30 & 100.5 & 5.53 \\
\hline Broker commission & 20 & - & 25 & 30 & - & 75 & 4.13 \\
\hline Space/house rent & - & 22.5 & 15 & 15.5 & 30 & 83 & 4.57 \\
\hline Bazar toll & 10 & - & 10 & - & - & 20 & 1.10 \\
\hline Tips and donation & 10 & 10 & 25.5 & 30 & 20 & 95.5 & 5.26 \\
\hline Electricity & - & 3.3 & 1 & 3 & 5 & 12.3 & 0.68 \\
\hline Telephone bill & 3 & 4 & 5 & 7.5 & 7.5 & 27 & 1.49 \\
\hline Damage & - & 15 & 40.5 & 75.5 & 150 & 281 & 15.48 \\
\hline Personal expenses & 10 & - & 12.5 & 15 & 17.5 & 55 & 3.03 \\
\hline Others & - & 3 & 12.5 & 15.5 & 15 & 46 & 2.53 \\
\hline Total & 174.5 & 109.8 & 451.5 & 533 & 547 & 1815.8 & 100 \\
\hline
\end{tabular}

Here $n=10$ 
Table 6. Total marketing costs of different intermediaries involved in Acacia auriculiformis firewood marketing

\begin{tabular}{|c|c|c|c|c|c|c|}
\hline \multirow{2}{*}{$\begin{array}{c}\text { Cost Items } \\
1 \mathrm{mon}=40 \mathrm{~kg}\end{array}$} & \multicolumn{4}{|c|}{ Intermediaries } & \multirow{2}{*}{ Total } & \multirow{2}{*}{$\%$ of total costs } \\
\hline & Farmer & L. Trader & Wholesaler & Retailer & & \\
\hline Timber harvesting & 7.5 & - & - & - & 7.5 & 9.20 \\
\hline Transportation & 2.5 & 7.5 & 12.5 & 10.5 & 33 & 40.49 \\
\hline Labor wages & 2 & 3 & 4 & 3 & 12 & 14.72 \\
\hline Space/house rent & - & 0.5 & 0.5 & 1 & 2 & 2.45 \\
\hline Bazar toll & 0.5 & 1 & 1 & - & 2.5 & 3.07 \\
\hline Tips and donation & 0 & 1.5 & 2 & 3 & 6.5 & 7.98 \\
\hline Electricity & - & 0.2 & 0.3 & 0.5 & 1 & 1.23 \\
\hline Telephone bill & 0 & 1 & 1.5 & 1.5 & 4 & 4.91 \\
\hline Personal expenses & 0.5 & 2 & 1.5 & 3 & 7 & 8.59 \\
\hline Others & 0 & 1.5 & 2 & 2.5 & 6 & 7.36 \\
\hline Total & 13 & 18.2 & 25.3 & 25 & 81.5 & 100.00 \\
\hline
\end{tabular}

Here $n=10$

Table 7. Marketing margins of agroforestry products

\begin{tabular}{ccccc}
\hline Produces & Unit & Producer price (Taka), P & Retail price (Taka), R & Marketing margin $=(\mathbf{R}-\mathbf{P}) / \mathbf{R} * \mathbf{1 0 0}$ \\
\hline Pineapple & $1 \mathrm{no.}$ & 10 & 35 & $71.43 \%$ \\
Ginger & $1 \mathrm{~kg}$ & 70 & 125 & $44.00 \%$ \\
Turmeric & $1 \mathrm{~kg}$ & 30 & 45 & $33.34 \%$ \\
Firewood (Acacia) & $1 \mathrm{mon}(40 \mathrm{~kg})$ & 120 & 190 & $36.84 \%$ \\
Firewood (Gamar/Bokain) & 1 mon (40kg) & 100 & 175 & $42.86 \%$ \\
\hline
\end{tabular}

$1 \mathrm{US} \$=79$ Taka (local currency)

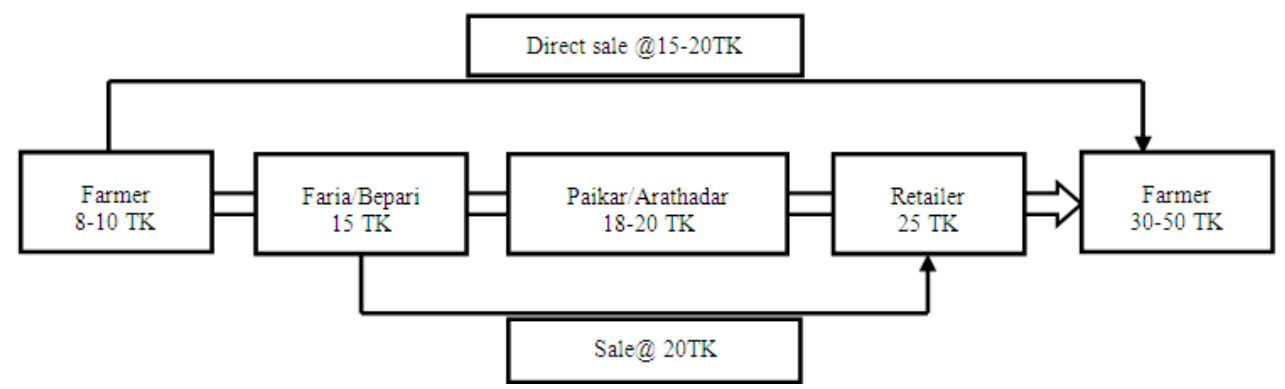

Figure 8. Value addition of a pineapple in marketing channel

\section{Discussion}

Analysis of different types of intermediaries especially network and value added structures have enriched this study's picture of how these channel works and what is needed to improve them further. Based on this study's results it was clear that the presence of many intermediaries made the value chain complex and problematic, especially for the farmer and the consumer. In case of agroforestry crops, the vertical networks identified six different channels and the main and longest channel consists of phoria, bepary, paiker/arathdar and retailer. Farmers sold their 87\% pineapples to their next level intermediaries (Table 3) and pineapples passed through the main and longest network structure to reach the ultimate consumer. In a study of Potato, Scott (1988) also observed that farmer were inclined to sell their complete crop to local bepari and in some cases to phoria at home. In a firewood study on Nepal, Dhital (2004) also reported that most of the firewood/timber buying and selling operations are transacted by the wholesalers and farmers often suffered from the low price of their products. The study also identified several long network structures for timber products, and FD run agroforestry timber selling process has solely controlled by the auctioneer/buyer. Almost 99\% farmer claimed that buyers have negotiated prior to the auction process in order to set a lowest or minimum price of firewood. Farmer also reported the same for crops selling process where beparies were the main controller. These types of negotiation or coalition was also reported by Islam and Sato (2012b) and Gain (2002) in their studies on Sal forests of Bangladesh. Local government or authority did not pay any attention to this issue or even there was no strong market monitoring cell was formed by local government. Almost every farmer claimed that neither the local government strictly monitored market nor did any action to abolish intermediaries' coalition at local level.

Another important aspect of network structure is its vertical dimension and the existing relationship of the same group/level of stakeholders in the value chain. Results revealed that farmers did not possessed a strong positive relationship among them; thus, they cannot negotiate to fix products selling price at market. Due to a strong positive relationship intermediaries (e.g. Bepary) negotiated among them and controlled the initial buying prices of the 
agroforestry crops in the local market, which was also reported by Islam and Sato (2012b). Moreover, farmers had possessed the worst relationship to their next level of intermediaries (e.g. Bepary) to whom they sold most of the products (Figure 7). Often farmers faced prefixed prices of their products, such as pineapples or gingers set by the beparies. So, farmers were treated the less powerful actor in every network structures. Similar types of results also reported by Ahmed 2007; Asogwa and Okwoche 2012; Alam 2012; Islam et al 2013; Daital 2004 in their studies. Farmer cooperative organization has been implemented by farmer as one of the best possible solution to exclude unexpected intermediaries from network structures $(4,47$; 48, 49. The cooperative should be an independent local association in which the opinion and action of each member have been treated equally. The main tasks of the study area's cooperative would be to collect members' products for sale and also ensure other marketing functions. This will secure the farmer rights and also abolish the unexpected intermediaries' intervention in marketing channel. These cooperatives would bring the farmer one step closer to the final consumer with his products, and both of them will be eventually benefited.

Value added could easily explain the amount of added price for each products in marketing channel. When agroforestry products moves through value chains, every intermediary adds some extra costs together with real costs. So, the higher the number of intermediaries involved in value chain the higher the products price which was clearly visualized in Figure 8 for a pineapple product. Majority of the products value addition incurred to transportation costs which would easily decreased by deducting the intermediaries from value chain. There were also some unexpected costs such as tips and donations, bazar toll, and these would easily minimized by proper execution of marketing regulations. Regarding to marketing margins, pineapple marketing margin (71\%) was extremely high compare to other products marketing margin of around $40 \%$. So, the variations of farmer and retail prices, especially for agroforestry crops, clearly indicated that farmers received only a minor share of the final retail prices. Empirical evidence to support this finding is very inadequate in Bangladesh; however, Scott (1988) found similar type of results in potato marketing systems in Bangladesh. In mango marketing, Matin et.al (2008) also found a high marketing margin in several districts level markets of Bangladesh. Nevertheless, other developing countries also showed higher marketing margins for crops marketing systems $[15,45]$. So, there is an immediate need to reduce the marketing costs as well as marketing margins in order to stable the agriculture and small scale forestry marketing systems in Bangladesh and other developing countries that possess the similar situations.

\section{Conclusion}

Agroforestry products value chains examined here are very important in Bangladesh and other developing countries because they offer substantial opportunities for domestic farmers to increase their production and income. Value chain analysis of agroforestry products has been characterized by the involvement of many intermediaries; thus, marketing channels were long and complex in Bangladesh. Often involvement of some intermediaries seems to be redundant; their presence just adds an extra cost to the consumer, creating high marketing margins. Most of the costs incurred in value chain were on transport the agroforestry products from farmer field to retailer places. These transport costs added a significant amount of value addition to products. Moreover, lack of strong positive relationship among the farmers placed them as a less powerful actor in every network structure. It may, thus can be summarized from the study that farmers' free fair access and benefits seemed to be very minimum in the present value chain, while costs of marketing, intermediaries' intervention and value addition were high.

Although the value chain analysis of agroforestry products in Bangladesh is overwhelmed by many complications, there have been a plenty of policy options that are expected to improve the systems. There is an immediate need to establish farmer cooperatives or an independent local associations, especially to help the farmers' products to sell and to help farmers to purchase their needed supplies. These cooperatives can significantly reduce intermediaries from network structure and also integrating farmer horizontally in order to acquire the right and power over powerful intermediaries who dominate and control the price of agroforestry products. The better option to reduce the transportation costs is to adopt the system whereby few experienced individuals (e.g. cooperative members) may transport the products belongings to several stakeholders to markets. The local government should also arrange adequate supports to farmer cooperatives and also play an active role in providing physical facilities. Finally, the government should review and harmonizing existing marketing legislation as well as strictly follow marketing regulation in order to ensure transparency and controlled any types of intermediaries coalition. This will intern ensure free and fair marketing systems of crops and small scale forestry products, and also ensure the pace of economic development of the country.

\section{Acknowledgment}

This study was carried out in the context of research funded by the Japan Society for the Promotion of Science (JSPS) fund.

\section{References}

[1] K.N. Huda, M.R. Karim, and R.S. Khan. An empirical study on competitive distribution management of tea brands in Bangladesh. International Journal of Marketing Studies, Vol. 4, No. 5, pp. 99-107, 2012. 
[2] S. Kapoor, and P. Kansal. Marketing logistics: a supply chain approach. Indian Branch Pearson Education, Singapore, 2003

[3] A. Dorward, J. Kydd, and C. Poulton. Traditional domestic markets and marketing systems for agricultural products. World Development Report Background Paper No. 41359, 2008 .

[4] R.L. Kohls, and J.N. Uhl. Marketing for agricultural products. Macmillan publishing, New York, 2002.

[5] R. Kaplinsky, and M. Morris. A Handbook for Value Chain Research. Prepared for International Development Research Centre (IDRC) (Part 1), 2000.

[6] M.E. Porter. The Competitive Advantage of Nations. Simon \& Schuster Publication, USA, 1990.

[7] L. Kirimi, N. Sitoko, T.S. Jayne, F. Karin, M. Muyanga, M. Sheahan, J. Flock, and G. Bor G. A Farm Gate-To-Consumer Value Chain Analysis of Kenya's Maize Marketing System. MSU International Development Working Paper No 111, 2011, http://fsg.afre.msu.edu/papers/idwp111.pdf . Accessed 8 April 2014.

[8] E.R. Jacinto. A research framework on value chain analysis in small scale fisheries, 2004 http://ageconsearch.umn.edu/bitstream/139883/2/2006_mul doon.pdf . Accessed 28 March 2014.

[9] A.K. Dey, and B.N. Banerjee. Production and marketing of pulses and oilseeds. New Delhi, India. Mittal Publication, 1991.

[10] R.M. Al-Hassan, D.B. Sarpong, and A. Mensah-Bonsu. Linking smallholders to markets. Ghana Strategy Support Program (GSSP) Background Paper No. 01. Accra, Ghana, 2006.

[11] M.F. Alam, M.S. Palash, M.I.A. Mia and M.M. Dey. Marketing of major fish species in Bangladesh: a value chain analysis. Food and Agriculture Organization Report, Rome, Italy, 2012.

[12] G.J. Scott. Marketing Bangladesh's potato: present patterns and future prospects. CIP- ADAB, Dhaka, Bangladesh, 1988

[13] K.K. Islam, Kimihiko. Hyakumura, Fujiwara. Takahiro, and Sato. Noriko. Confronting people-oriented forest management realities in Bangladesh: An analysis of actors' perspective. International Journal of Social Forestry, Vol. 4, No. 2, pp.153-179, 2011.

[14] K.K. Islam, and Sato. Noriko. Participatory forestry in Bangladesh: Has it helped to increase livelihoods of Sal forests dependent poor people. Southern Forest, Vol.74, No. 2, pp. 89-101, 2012a.

[15] B.C. Asogwa, V.A. Okwoche. Marketing of agricultural produce among rural farm household in Nigeria: the case of Sorghum marketing in Benue State. International Journal of Business and Social Science, Vol. 3, No. 13, pp. 269-277, 2012.

[16] M. Roy. Agricultural marketing: new challenges. International Journal of Humanities and Applied Sciences, Vol. 1, No. 2, pp.2277-4386, 2012

[17] D. Prakash. Capacity building of agricultural cooperatives to meet the market and human resources development demands. Pamda-Network International, New Delhi, India, 2000 .

[18] C. Giagnocavo. The Almeria agricultural cooperative model: creating successful economic and social communities. Report for UN Division for Social Policy and Development, Department of Economic and Social Affairs. pp.1-9, 2012.

[19] T. Term. Smallholders' agricultural cooperatives and rural development in Colombia. Dissertation, Public Policy in Latin America, the University of Oxford, 2011.

[20] OCDC (US Overseas Cooperative Development Council). Cooperatives: Pathway to economic, democratic and social development in the global economy, 2007.http://www.acdivoca.org/site/Lookup/OCDC_Pathway s_Paper/\$file/OCDC_Pathways_Paper.pdf . Accessed 2 April 2014.

[21] M.M. Ali, and A.M. Islam. Developing agribusiness strategies for Bangladesh: an analysis. AIUB Bus Econ Working Paper Series No 2011-01. http://orp.aiub.edu/. Accessed 29 November 2013.

[22] World Bank. Agriculture in South Asia, 2011. http://go.worldbank.org/770VR4DIU0. Accessed 22 November 2013.

[23] S. Raihan, and M. Ahmed. Service trade liberation and domestic regulation: perspective from Bangladesh. MPRA (Munich Personal RePEc Archive) Paper No. 37896, 2008.

[24] K.K. Islam, M.O. Ullah, M. Hoogstra, and Sato. Noriko. Economic contribution of participatory Agroforestry program to poverty alleviation: a case from Sal forests, Bangladesh. Journal of Forestry Research, Vol. 23, No. 2, pp. 323-332, 2012.

[25] M.S. Safa. The effect of participatory forest management on the livelihood of the settlers in a rehabilitation program of degraded forest in Bangladesh. Small-scale Forest Economics, Management and Policy, Vol. 3, No. 2, pp. 223$238,2004$.

[26] K.K. Islam, Sato. Noriko, and M. Hoogstra. Poverty alleviation in Bangladesh: The case of the participatory agroforestry program. International Forestry Review, Vol.12, No. 5, pp. 412-415, 2010.

[27] K.K. Islam, G.M. Rahman, Takahiro. Fujiwara, and Sato. Noriko. People's participation in forest conservation and livelihoods improvements: Experience from a forestry project in Bangladesh. International Journal of Biodiversity Science, Ecosystem Services \& Management, Vol. 9, No. 1, pp. 30-43, 2013.

[28] N. Muhammed, M. Koike, F. Haque, and M.D. Miah. Quantitative assessment of people oriented forestry in Bangladesh: A case study from Tangail Forest Division. Journal of Environmental Management, Vol. 88, No. 1, pp. 83-92, 2008.

[29] S.L. Lazzarini, F.R. Chaddad, and M.L. Cook. Integrating supply chain and network. Journal on Chain and Network Science, Vol.1, No.1, pp. 7-22, 2001.

[30] J.H. Trienekens. Agricultural value chains in developing countries: a framework for analysis. International Food and Agribusiness Management Review, Vol. 14, No. 2, pp. 51-82, 2001. 
[31] C.M. Webber, and P. Labaste. Building competitiveness in Africa's agriculture: a guide to value chain concepts and applications,

https://openknowledge.worldbank.org/bitstream/handle/109 86/2401/524610PUB0AFR0101Official0Use0Only1.pdf?se quence $=1$. Accessed 29 March 2014 .

[32] R.M. Ruben, A. van Boekel, van Tilburg, and J. Trienekens. Governance for quality in tropical food chains. Wageningen Academic Publishers, the Netherlands, 2007.

[33] L.W. Stern, A.I. El-Ansary, and A.T. Coughlan. Marketing channels. Prentice Hall-International, London, 1996.

[34] G. Gereffi, and M. Korzeniewicz. Commodity Chains and Global Capitalism. Praeger Publishers, USA, 1994.

[35] O.E. Williamson. Strategy research: governance and competence perspectives. Strategic Management Journal, Vol. 20, pp. 1087-1108, 1999.

[36] G. Gereffi, and R. Kaplinsky. The value of value chains: spreading the gains from Globalization. IDS Bulletin, Vol. 32, No. 3, 2001.

[37] O.E. Williamson. The economic institutions of capitalism: firms, markets, relational contracting. In: Trienekens JH (ed.) Agricultural value chains in developing countries: a framework for analysis. International Food and Agribusiness Management Review, Vol. 14, No. 2, pp.51-82, 1985.

[38] A. Rindfleisch, and J.B. Heide. Transaction cost analysis: past, present, and future applications. Journal of Marketing, Vol. 61, pp. 30-54, 1977.

[39] P. Gibbon, J. Bair, and S. Ponte. Governing global value chains: an introduction. Economy and Society, Vol. 37, No. 3, pp. 315-338, 2008.

[40] FD (Bangladesh Forest Department). Protected areas of Bangladesh. Ministry of Environment and Forest Government in Bangladesh, 2013. http://www.bforest.gov.bd/ . Accessed 30 November 2013.
[41] K.K. Islam, and Sato. Noriko. Deforestation, land conversion and illegal logging in Bangladesh: The case of the Sal forests. $i$ Forest- Biogeoscience and Forestry, Vol. 5, pp. 171-178, 2012.

[42] BBS (Bangladesh Bureau of Statistics). Statistics data, 2006. http://www.bbs.gov.bd. Accessed 2 December 2013.

[43] P. Gain. The last forest of Bangladesh. Society for Environmental and Human Development (SEHD), Dhaka, Bangladesh, 2002.

[44] S. Tasnoova, and I. Iwamoto. Kataribjog rice marketing system in Dinajpur District, Bangladesh. Faculty of Agriculture Kagoshima University, Vol.41, pp.19-50, 2006.

[45] R. Dhital. Rural urban agriculture marketing system: challenges and opportunities: a case study: Eastern Nepal. Dissertation, School of Forestry and Environmental Studies, Yale University, USA, 2004.

[46] N. Ahmed. Value chain analysis of Hilsa marketing in coastal Bangladesh. Agriculture News, Vol. 33, pp.18-28, 2007.

[47] D. Sarker, and B.K. Ghosh. Milk marketing under cooperative and no-cooperative marketing channels: experiences from West Bengal. Economic Analysis, Vol. 55, No. 187, pp. 87-108, 2010.

[48] A.K. Ghosh, and K.I. Maharjan. Impacts of dairy cooperative on rural income generation in Bangladesh. Journal of International Development and Cooperation, Vol. 8, No. 1, pp. 91-105, 2001.

[49] N.A. Kwapong. Restructured agricultural cooperative marketing system in Uganda: study of the tripartite cooperative model. Euricse Working Paper No. 57/13, 2013.

[50] M.A. Matin, M.A. Baset, Q.M. Alam,, M.R. Karim, and M.R. Hasan. Mango marketing system in selected areas of Bangladesh. Bangladesh Journal of Agricultural Research 33(3): 427-438. 